\title{
Consumtivism on Touring Master's Students In Jakarta
}

\author{
LINDA K. WEDARI \\ Universitas Katolik Indonesia Atma Jaya, Faculty of Economics and Business, Jakarta 12930, Indonesia \\ Email correspondence: lindakusumaningwedari@yahoo.com
}

\begin{abstract}
This study about the factors that influence he decision on tourism destination of Master's students from 9 (nine) Universities in Jakarta. Around 199 questionnaires that were returned, had been processed by using binary logistic regression, for tour in Java, tour outside of Java, domestic tourism, and tour overseas. The researcher finds that, First, respondents make expenditures for meals, snacks, entrance fees, game with consumptive. While spending on hotels, their clothes, clothes for gift, souvenirs and snacks for gift with highly consumptive. Second, factors that encourage a trip decision to Java and outside Java, are income and plan (respondents prepared it by their monthly saving) while factors that influence them to have trip in the country (domestic)or overseas, are motivation, spending, and income. Third, for both trip to Java Island and outside Java Island, and also tourism domestic destinations as well as overseas, most respondents choose to pay their cost by their own cash or by their own credit card for the range of 1-6 months payment.
\end{abstract}

Key words: Tourism destination, motivation, financing and buying behavior.

\section{Konsumtivisme pada Tur Para Mahasiswa Master Di Jakarta}

\begin{abstract}
Abstrak
Penelitian ini tentang faktor-faktor yang mempengaruhi keputusan ia tentang tujuan wisata dari para mahasiswa master dari 9 (sembilan) Perguruan Tinggi di Jakarta. Sekitar 199 kuesioner yang dikembalikan, telah diolah dengan menggunakan regresi logistik biner, untuk tur di Jawa, tur di luar Jawa, pariwisata domestik, dan tur di luar negeri. Peneliti menemukan bahwa, Pertama, responden melakukan pengeluaran untuk makanan, makanan ringan, biaya masuk, game dengan konsumtif. Sementara menghabiskan hotel, pakaian mereka, pakaian untuk hadiah, souvenir dan makanan ringan untuk hadiah dengan sangat konsumtif. Kedua, faktor yang mendorong keputusan perjalanan ke Jawa dan luar Jawa, adalah pendapatan dan rencana (responden disiapkan dengan tabungan bulanan) sedangkan faktor yang mempengaruhi mereka untuk memiliki perjalanan di dalam negeri (domestik) maupun di luar negeri, yang motivasi, belanja, dan pendapatan. Ketiga, untuk kedua perjalanan ke Pulau Jawa dan luar Pulau Jawa, dan juga pariwisata tujuan domestik maupun luar negeri, sebagian besar responden memilih untuk membayar biaya mereka dengan uang mereka sendiri atau dengan kartu kredit mereka sendiri untuk berbagai pembayaran 1-6 bulan.
\end{abstract}

Kata kunci: Tujuan pariwisata, motivasi, pendanaan dan perilaku pembelian. 


\section{INTRODUCTION}

Consumptivism is the decision processes and acts of people involved in buying and using products. Berkman and Gilson (1978) argued that a purchasing behavior is the sequential activity from buying intention to actual purchasing behavior. A consumptive person perceives that the measurement of pleasure or happiness is when he can buy goods or services without considering whether he really needs them or not.

For some people, especially those who love travelling, vacation is a necessity. It is caused by some factors such as the high buying power, sense of concern towards the quality of family relationship or social relationship which can be established through refreshment, especially refreshment in an open space, internet connection, and promotion program or interesting package of vacation provided by travel agent (e.g. year end holidays package), etc.

According to Ali (2010), the highest spending for vacation among all demographic age groups is on the youth group ( $20-24$ years old) which is $10.4 \%$ per month. Young people in this group usually do not have their own income and still depend on their parents. Although most of them are student, their spending on vacation and entertainment is the highest among all age groups. In this initial study, the researcher wants to identify what factors that underlie someone's preference on touring. Analysis will be conducted on three groups of tourism destinations which are Java Island, Outside of Java Island, and Overseas.

Referring to those backgrounds, this study will try to answer the research questions i.e. What factors that determine in chosing the destination? How is the consumptive behavior of master's students? And how do they finance their tour? The purposes of this study are to identifies the factors in determining tourism destination and to analyze how they finance their tour, so the marketers could consider thepromotion strategies.

\section{LITERATURE REVIEW}

\section{The need of recreation}

Life of human being is marked and structured by some main factors which define who we are and how we live. Basically, human being need to be individual and social being. Human basic needs as individual are breathing, eating, drinking, sleeping, showering, defecating, and urinating. If those needs are not fulfilled, then they could not live. As a creature who has senses, those needs not only have to be fulfilled but also have to create self-satisfaction. The need for pleasure or fun are basically found on the needs of our five senses such as eyes, nose, ears, tounge, and skin, until it reaches the certain level of satisfaction.

Sense of sight can be satisfied by seeing attractive and beautiful shape. Sense of hearing can be pleased by listening to beautiful and melodious voice. Sense of smell can be met by sniffing fragrant and fresh smell. Sense of taste can be delighted by feeling the temperature and tasting pleasing objects. If the needs are filled continously with the same treatments, then there will be a sick situation that at some point can create depression and even craziness for the person. Therefore, someone has to please its five senses to swap away the sickness of routines activities by going on tour to a near place or a far place. Recreation is essential to meet the psychological need that is able to reduce stress by doing activities such as crafting or carving (Hurd\&Anderson., 2011).

Consumptivism is an expression of culture and manifestation of consumptive action. Consumptivism is patterns of consumption characteristics such as spending spree, extravagance of money, and the change of satisfication feeling on things which can be delayed to be things that need to be fulfilled quickly (Lamarto, 1985). Consumptive behavior causes someone to always feel unsatisfied and being neglected on how to get it.

Consumptive behavior is someone's manner which is controlled by a desire to meet his secular happiness. Lubis (1993) mentions that consumptive behavior is a buying action which is no longer based on the rational considerations but because there is a need to reach irrational level of satisfication.

Motivation is fundamental in study of tourist and tourism because it is the trigger of vacation process, although it is often not realized by the tourist (Sharpley, 1994). 
Consumtive Behavior of Youth Tourist in Tourism Destination

Higgins-Desbiolles (2010) examines the cultural ideology of consumerism in relation to the sustainability of tourism. Their research ensuring ideological implications of consumerism culture theory remains useful in the issue of sustainable tourism. Mullins (1999) stated that researchers regard to urban researchers in substance ignores the link among consumerism, tourism and urban.

Young age is usually identical to consumtivism because of its identities which are like a short-term thinker and an easy person to be influenced by some stimuli. Someone can be very consumptive because he gets some stimuli from his environment. Young people are susceptible of those stimuli because they still involve in many activities in society, in which it make them become part of society who can easily act very consumptive. Young people who stay in the tourism areas have higher level of consumptive behavior than those who stay in non-tourism places. It is understandable because those who stay in tourism area get direct stimuli from their environment.

\section{Previous Study}

In Ismail, Panni and Talukde (2006), Ismail and Panni (2008) about consumer perception on their purchasing behavior on food industry in Malaysia, found that consumerism relates to the buying behavior of the consumers. Ismail and Panni (2008) investigated consumer perceptions on the issues and its influence on their purchasing behavior: a view from Malaysia Food Indusry. They found that consumerism relates to the buying behavior of the consumers. Similar with the study of Imail, Panni and Talukder (2006) about consumer perceptions on the environmental consumerism issue and its influence on their purchasing behavior. Ismail et.al (2006) found that consumerism behavior has positive relation to the buying behavior of the consumenrs (on food products).

Ware (2002) in the study of consumerism with credit card bycollage student found that system of technology with profit orientation, laxity of government's profit regulation, adolescent social pressure, reduction of parent's saving and increase of spending have been worsening this bad situation. However, the use of credit card unwisely by the students themselves have proved that it is the main cause on this problem. Orel, Demirci, and Zeren (2011) stated there are different consumptivism behaviors between the students and the government's regulations in Poland and Turkey. However, business still needs to identify and deal with every consumer's significant complaint that probably shows up and offers possible solutions which can be developed. If consumers' benefits are the main purpose, the awareness of consumptivism shall have been developed in both countries.

Enrico, Aron and Oktavia (2014) investigated the factors that influenced consumptive behavior: A Survey of University Students in Jakarta. They found that There are some dominant causes that affect consumptive's behavior such as buying power and the use of product, social status, satisfaction, and prestige. It is quite similar to the research by Hotpascaman except for hypothesis on family lifestyle which can be accepted.

Ali and Wisniesk (2010) found in the study that participants in UEA scored high both in consumtivism and consumers' ethics. However, tendency of buying and enjoying shopping is not shown on the low score of consumers' ethics. On the other hand, there seems a positive relation between consumptivism and scale of consumers' ethics. Demeter and Bratucu (2014) stated that there are some kinds of tourism done by youth tourists. European young tourists show tendency that a bit different from Rumanian tourists. European tourists tend to do culture exchange and be volunteer while Rumanian tourist prefer to do adventure and sport travel. However both of them like education tourism.

Jones, Hillier, Comfort and Eastwood (2005) in the study sustainable retailing and consumerism, found that retailer believes that the sustainability of long term economic is on the interests of all stakeholders, and if their businesses' continuity are integrated, they will be in better positions to provide financial and long term growth to all stakeholders.

Based on those previous studies, it can be seen that existing studies only focused on consumer goods, and there have not been any studies, especially in Indonesia, that focus on vacation (touring) 
consumerism.

\section{Hypothesis Development \\ Gender and Tourism Destination}

Women are considered as being warm, expressive, compassionate, and understanding. For women, the promotions emphasised beauty and youth. Men tend to buy instrumental and leisure items otherwise women tend to buy symbolic and self expressive goods. Women's perception stated that there is a pride in the ability to be prudent and get the best products for the best prices. Marketers empathize greatly by placing selective deals to offer a sense of accomplishment for women's shopping experience. Marketers can not promote to men the same way they do to women due to the fact that both genders are "different biologically, psychologically, and socially. According to Solomon (2012), there is a difference in gender buyer behavior which lead to differences in gender buyer decisions. Such as tourism destination, kind of food, hotels, etc.

\section{H1: Gender (X1) influence the Tourism Destination.}

\section{Motivation and Tourism Destination}

In making decision of tourism destination, responden motivated by curiosity of the new tourism places. Motivation is the trigger of the process of travel, even if the motivation is often not realized in full by tourists (Sharpley, 1994). The motivation can be grouped into: physiological motivation, cultural motivation, social motivation (interpersonal motivation), and fantasy motivation. Grande (2005) stated that consumers seek variety as a break from routine and that it is a process which varies in intensity according to the exploratory tendency of each individual. This variety seeking continues until the consumers reach the level of sensation or enjoyment in the process that suits their own characteristics. People who are clearly identified with their innate exploratory tendency possess an intrinsic motivation. Litvin (2008) suggests that sensation seeking has often been considered by tourism researchers.

\section{H2: Motivation (X2) influence the Tourism Destination.}

\section{Financing and Tourism Destination}

The old rule of thumb is that a once-a-year vacation should cost about one week's salary, but there's really no algorithm that's right for everyone. It's a personal decision that depends on one's fixed expenses (housing, cars, student loans, insurance) and lifestyle choices. To make choices of tourism destination, one's would prefer to use credit card rather than cash so they can make long distance trip (abroad).

\section{H3: Financing (X3) influnce the Tourism Destination.}

\section{Buying Behavior and Tourism Destination}

Life style is an individual's system regarding his/ her interests, ideas, opinions, actions, consuming habits. As the purchase and consumption of the tourism product is often separated by space and time (Litvin \& Ling, 2000). Potential first time visitors are unable to fully examine product attributes prior to purchase and therefore increase their reliance on image in destination choice (Chon, 1990). Only those destinations that offer an appropriate product, at an appropriate price, communicate these attributes effectively and sell the product through appropriate distribution channels will be considered for purchase.

\section{H4: Buying Behavior (X4) influence the Tourism Destination.}

\section{Income and Tourism Destination}

The economic factors are the most sensitive to environmental change and, as a result, they have been very affected by the economic situation of the past two years. For some people, travel is important enough that they choose to live in a smaller house and keep a lot of their discretionary expenses down so they can see the world. Profession also has a great impact on choosing tourism behavior because profession is related to the education level and their income level (Fratu, 2011).

The low income, the economic and financial instability had an impact on the European consumer, especially regarding tourism consumption. Given these conditions of economic instability, the European tourism consumer has changed his behavior looking for shorter trips, special offers and discounts, short distance trips, eventually city-breaks. Also, tourists have become very careful when spending money for travel. They are willing to assign a smaller amount of money to travel than in previous years, and they 
want to be sure that they benefit of the maximum of services (Fratu, 2011).

\section{H5: Income (X5) influence the Tourism Destination.}

\section{Plan on Tourism Spending and Tourism Destination}

Tourism agencies promote cheaper tourism packages and special offers. The early-booking concept became very popular because tourists prefer to pay in advance for a trip in order to benefit from a discount. Also e-tourism has developed a lot because tourists can create their own tourism packages on the internet, at the desired costs.

Romanian tourists reduced the budget allocated for travel. If in 2008 lots of tourists took loans in order to go on vacation, in 2009 and 2010 their behavior changed considerably. They think twice before taking a decision, regarding the fact that the amount of money used for the vacation can be used in other purposes. Some even gave up the thought of vacation. The low income, the rising prices, the instability of the work place, all these are reasons for which people think twice before deciding to spend money (Radbata, 2010). Given these conditions, travelling becomes for many Romanians a luxury.

H6: Plan on Tourism Spending (X6) influence the Tourism Destination.

\section{RESEARCH METHODS}

\section{Population and Sample}

Population of this study is all students in Master's Degree Program in universities in Jakarta. The use of these students as youth tourist respondents is because it is assumed that they have been working and have stable income so that they have power to define and plan its tour, and also have ability to finance themselves for the tour. The sampling technique in this study is Multi Stage Random Sampling which means the sampling technique is performed in stages and usually is based on the division of labor. This sampling techniqe is part of probability sampling technique.

\section{Method of Data Analysis}

First Test of Validity and Reliability, second Descriptive Statistical Data and Analysis of Binary Logistic
Regression, third Mean score.

Analysis of Binary Logistic Regression is used to see the factors that influence the decision making on touring. The format of double regression model on this study is as follows:

$\mathrm{g}(\mathrm{x} 1)=$ Tourism destinations are Java Island and Outside of Java Island

$\mathrm{g}(\mathrm{x} 2)=$ Tourism destinations are domestic and overseas.

Variable Value $\mathrm{g}(\mathrm{x})$ will be predicted based on Independent Variable $(X)$ consist of:

X1 = Gender

$\mathrm{X} 2$ = Motivation

$\mathrm{X} 3$ = Financing

$\mathrm{X} 4$ = Buying Behavior

$X 5=$ Income

$\mathrm{X} 6=$ Plan on tourism spending

$\beta 0=$ Intercept or constant.

Mean Score is used to analyze buying behavior and the tourism spending. The researcher analyzes by using mean score from each question.

\section{DISCUSSION}

$g(x)=\ln \frac{\pi(x)}{[1-\pi(x)]}=\left(\beta_{0}+\beta_{1} x_{1}+\ldots \ldots+\beta_{p} x_{p}\right)$

\section{Test of Reliability and Validity}

Before the questionnaires distributed, the researcher had examined the validity and reliability of each questions with 30 answers from initial distribution (Ferdinand,2014). Reliability test will use Cronbach's Alpha Test, in which according to Sekaran (2010:157), if the value of Cronbach's Alpha is over 0.6, the statement or variable made is reliable. The result of reliability test is as follow:

Table 4.1 Result of Reliability Test

\begin{tabular}{lccc}
\hline \multicolumn{1}{c}{ Variable } & Cronbach'c Alpha & N of Items & Explanation \\
\hline Motivation & 0.844 & 15 & reliabel \\
Financing & 0.663 & 5 & reliabel \\
Buying & 0.737 & 8 & reliabel \\
Behaviour & & & \\
\hline
\end{tabular}

The validity is examined by using Pearson correlation. 
The question is valid if it has p-value < alpha 0.05 or has value of Pearson correlation more than table of $R$ value $(0,361)$. The following table is the result of validity test that has been done.

Table 4.2 Result of Validity

\begin{tabular}{|c|c|c|c|}
\hline Variable & Statement & $\begin{array}{l}\text { Pearson } \\
\text { Corelation }\end{array}$ & Explanation \\
\hline \multirow[t]{13}{*}{ Motivation } & M1 & 0.517 & Valid \\
\hline & M2 & 0.597 & Valid \\
\hline & M3 & 0.394 & Valid \\
\hline & M4 & 0.621 & Valid \\
\hline & M5 & 0.527 & Valid \\
\hline & M6 & 0.693 & Valid \\
\hline & M7 & 0.720 & Valid \\
\hline & M8 & 0.749 & Valid \\
\hline & M9 & 0.647 & Valid \\
\hline & M10 & 0.394 & Valid \\
\hline & M11 & 0.563 & Valid \\
\hline & M12 & 0.620 & Valid \\
\hline & M13 & 0.608 & Valid \\
\hline \multirow[t]{5}{*}{ Financing } & B01 & 0.443 & Valid \\
\hline & B02 & 0.831 & Valid \\
\hline & B03 & 0.632 & Valid \\
\hline & B04 & 0.663 & Valid \\
\hline & B05 & 0.712 & Valid \\
\hline \multirow{9}{*}{$\begin{array}{l}\text { Buying } \\
\text { Behaviour }\end{array}$} & P011 & 0.765 & Valid \\
\hline & P121 & 0.514 & Valid \\
\hline & P031 & 0.511 & Valid \\
\hline & P041 & 0.467 & Valid \\
\hline & P051 & 0.510 & Valid \\
\hline & P061 & 0.418 & Valid \\
\hline & P071 & 0.743 & Valid \\
\hline & P081 & 0.749 & Valid \\
\hline & P091 & 0.643 & Valid \\
\hline
\end{tabular}

Based on that result, it can be emphasized that all statements used are valid, so that all data that have been taken by using questionnaire have already met the requirements.

\section{Descriptive Statistics}

\section{TOURISM DESTINATION IN JAVA ISLAND AND OUTSIDE OF JAVA ISLAND (DOMESTIC)}

Based on table 4.3, it can be seen that the youngest respondent is 22 years old and the eldest respondent is 57 years old, with the average respondents are on their 32 years old. It means that the respondents are still in their productive stage. The minimum income of respondent is 1.000.000 IDR and the highest income is $50.000 .000 \mathrm{IDR}$, and the average income is 7.898.148,15 IDR.

Tabel 4.3 Descriptive Statistic 1

\begin{tabular}{lccccc}
\hline & N & Min & Max & Mean & Std. Deviation \\
\hline Age & 189 & 22 & 57 & 32.2 & 8.598 \\
Income & 189 & 1000 & 50000 & 7898.14 & 5808.729 \\
Motivation & 189 & 26 & 58 & 43.709 & 5.62621 \\
Financing & 189 & 10 & 27 & 18.8042 & 2.64148 \\
$\begin{array}{l}\text { Buying } \\
\text { Behaviour }\end{array}$ & 189 & 9 & 44 & 26.5767 & 6.62207 \\
$\begin{array}{l}\text { Mounthly } \\
\text { Saving }\end{array}$ & 189 & 0 & 10000 & 606.878 & 1124.263 \\
$\begin{array}{l}\text { Valid N (list } \\
\text { wise) }\end{array}$ & 189 & & & & \\
\hline
\end{tabular}

For the variable of motivation, the lowest score of respondents' answer is 26 , and the highest score is 58 , with the average score is 43 , so the respondents' answers tend to be high. In the variable of financing, the lowest score is 10 and the highest score is 27 with the average score is 18.8, which means the score of respondents' answers tend to be high. The lowest score of variable of buying behavior is 9 , and the highest score is 44 with the average score of respondent is 26.57 which means it tends to be low. There are some respondents who do not reserve fund for tour, but there are also others respondents who make advanced saving with the highest number is 10.000.000 IDR and the average reserved fund is $606.787,31$ IDR.

Tabel 4.4 Descriptive Statistic 2

\begin{tabular}{llc}
\hline \multicolumn{1}{c}{ Ex. } & \multicolumn{1}{c}{ Explanations } & Frequency \\
\hline 1 & Destinations & 35 \\
& Java & 154 \\
& Outside of Java & 103 \\
\hline 2 & Status & 85 \\
& Married & 1 \\
& Single & 84 \\
& Widow & 105 \\
\hline 3 & Sex &
\end{tabular}


JURNAL BISNIS \& MANAJEMEN

ISSN 1412 - 3681

Continue of Tabel 4.4 Descriptive Statistic 2

\begin{tabular}{|c|c|c|}
\hline No. & Explanations & Frequency \\
\hline \multirow[t]{6}{*}{4} & Jobs & \\
\hline & Private & 127 \\
\hline & Government & 41 \\
\hline & Self-Employed & 13 \\
\hline & Foreign Cap Comp & 4 \\
\hline & State-Owned Enterprises & 4 \\
\hline \multirow[t]{6}{*}{5} & Payment Methods & \\
\hline & Own Cash & 120 \\
\hline & Cash From Parent & 14 \\
\hline & Own Credit Card & 38 \\
\hline & Parent Credit Card & 1 \\
\hline & Cash and Credit Card & 16 \\
\hline \multirow[t]{3}{*}{6} & Budget Planning & \\
\hline & No & 70 \\
\hline & Yes & 119 \\
\hline \multirow[t]{8}{*}{7} & Payment Period & \\
\hline & 0 & 140 \\
\hline & 1 - 3 months & 14 \\
\hline & $4-6$ months & 18 \\
\hline & 7 - 9 months & 11 \\
\hline & 12 months & 3 \\
\hline & $>12$ months & 2 \\
\hline & auto debit & 9 \\
\hline
\end{tabular}

Based on table 4.4. it can be seen that out of 189 respondents, there are $18.5 \%$ of them having vacation in Java Island and $81,5 \%$ of them having vacation in the Outside of Java Island. Thus, the majority of respondents, about 154 respondents, have been travelling to the outside of Java Island.

Around $54.5 \%$ of respondents have been married, 45 $\%$ is still single, and $0.5 \%$ is widow. Therefore, it can be concluded that majority of these respondents is married. The female respondents are about $44.4 \%$, and male respondents are $55.6 \%$, so that the majority of respondents is male.

The respondents' majority is working in private companies with score of $67.2 \%$, in government (civil servant) with score of $21.7 \%$, in its own private business is $6.9 \%$, in foreign capital companies with score of $2.1 \%$, and domestic owned-enterprises with score of $2.1 \%$.

Out of 189 respondents, there are $63.5 \%$ respondents who pay their tourism spending by their own cash money, and $20.1 \%$ who pay by using their own credit card. It is only few respondents who pay their tourism spending by using financial support or credit card of their close friend/family. There are $37 \%$ respondents who do not make budget planning for vacation and $63 \%$ respondents who make budget planning for its vacation scheme. It can be concluded that majority of these respondents have saved their money every month for their planned trip. Around $72 \%$ respondents use cash and only few of them that finance its tourism by using credit card.

\section{TOURISM DESTINATION DOMESTIC AND OVERSEAS}

Tabel 4.5 Descriptive Statistic 3

\begin{tabular}{|c|c|c|c|c|c|}
\hline & $\mathbf{N}$ & Min & Max & Mean & Std. Deviation \\
\hline Age & 197 & 22 & 57 & 32.38 & 8.48 \\
\hline Income & 197 & 1000 & 50000 & 8094.16 & 583.0009 \\
\hline Motivation & 197 & 26 & 60 & 43.9289 & 5.83576 \\
\hline Financing & 197 & 10 & 40 & 18.9797 & 3.10851 \\
\hline $\begin{array}{l}\text { Buying } \\
\text { Behaviour }\end{array}$ & 197 & 9 & 44 & 26.5228 & 6.60594 \\
\hline $\begin{array}{l}\text { Mounthly } \\
\text { Saving }\end{array}$ & 197 & 0 & 10000 & 621.065 & 1112.062 \\
\hline $\begin{array}{l}\text { Valid N (list } \\
\text { wise) }\end{array}$ & 197 & & & & \\
\hline
\end{tabular}

Based on table 4.5. it can be seen that the youngest respondent is 22 years old and the oldest respondent is 57 years old, with the average age is 32 years old. It means that the respondents are still in their productive age. The minimum income of respondents is $1,000,000$ IDR and the highest income is $50,000,000$ IDR, and with the average is 8,094,160.15 IDR.

For the variable of motivation, the lowest score of respondents' answer is 26 , and the highest score is 60 , with the average score is 43 , so the respondents' answers tend to be high. In the variable of financing, the lowest score is 10 and the highest score is 40 with the average score is 18.97, which means the score of respondents' answers tend to be high. The lowest score of variable of buying behavior is 9 , and the highest score is 44 with the average score of respondent is 26.52 which tends to be low. There are some respondents who does not have reserved fund for vacation, but there are also others respondents who make advanced saving with the highest number is 10.000.000 IDR and the average reserved fund is 
$621.065,99$ IDR.

Tabel 4.6 Descriptive Statistic 4

\begin{tabular}{|c|c|c|}
\hline No. & Explanations & Frequency \\
\hline \multirow[t]{3}{*}{1} & Destinations & \\
\hline & Java & 109 \\
\hline & Outside of Java & 88 \\
\hline \multirow[t]{4}{*}{2} & Status & \\
\hline & Married & 108 \\
\hline & Single & 87 \\
\hline & Widow & 2 \\
\hline \multirow[t]{6}{*}{4} & Jobs & \\
\hline & Private & 131 \\
\hline & Government & 42 \\
\hline & Self-Employed & 13 \\
\hline & Foreign Cap Comp & 7 \\
\hline & State-Owned Enterprises & 4 \\
\hline \multirow[t]{6}{*}{5} & Payment Methods & \\
\hline & Own Cash & 124 \\
\hline & Cash From Parent & 15 \\
\hline & Own Credit Card & 41 \\
\hline & Parent Credit Card & 1 \\
\hline & Cash and Credit Card & 16 \\
\hline \multirow[t]{3}{*}{6} & Budget Planning & \\
\hline & No & 70 \\
\hline & Yes & 127 \\
\hline \multirow[t]{8}{*}{7} & Payment Period & \\
\hline & 0 & 140 \\
\hline & $1-3$ months & 14 \\
\hline & $4-6$ months & 18 \\
\hline & 7 - 9 months & 11 \\
\hline & 12 months & 3 \\
\hline & $>12$ months & 2 \\
\hline & auto debit & 9 \\
\hline
\end{tabular}

Based on table 4.6. it can be seen that out of 197 respondents, there are $54.8 \%$ who are married, $44.2 \%$ who are single, and only $1 \%$ who are widow. Therefore, the majority of respondents is married. The respondents' majority work is in private companies with score of $66.5 \%$ and in government (civil servant) with score of $21.3 \%$. The rest of repsondents are working in its own private business is $6.6 \%$, in foreign capital companies with score of $3.6 \%$, and domestic owned-enterprises with score of $2.0 \%$.

There are $62.9 \%$ respondents who pay their tourism spending by their own cash money, and $20.8 \%$ who pay by using their own credit card. It is only few respondents who pay their tourism spending by using financial support or credit card of their close friend/ family. The majority of respondents who pay by using cash money is $71.1 \%$, anf only few of them who finance its vacation by using credit card. From the total of all respondents, the highest percent of respondent with economic background is $35 \%$ and then follows by the psychology background with $17.3 \%$.

\section{MODEL TESTING}

$Y$ (tourism destination) : Java and Outside of Java

Goodness of Fit Test

Tabel 4.7 Goodness of Fit Result

\begin{tabular}{cccc}
\hline Step & Chi-Square & df & Sig. \\
\hline 1 & 6.574 & 8 & 0.583 \\
\hline Hosmer and Lemeshow Test & &
\end{tabular}

\section{Overall Model Test}

By comparing the value between -2 Log Likehood on Block Number $=0$ and -2 Log Likehood on Block Number $=1$, because of the impairment, it means this regression model is fit with the data.

Table 4.8 Result of Overall Model Test Block 0: Beginning Block Iteration History ${ }^{\mathrm{a}, \mathrm{b}, \mathrm{c}}$

\begin{tabular}{cccc}
\hline & & & Coefficients \\
\cline { 3 - 3 } & Iteration & $\mathbf{- 2}$ Log likelihood & Constant \\
\cline { 3 - 4 } & & 182.153 & 1.255 \\
Step 0 & 1 & 180.719 & 1.462 \\
& 2 & 180.714 & 1.475 \\
& 3 & 180.714 & 1.475 \\
\hline
\end{tabular}

a. Constant is included in the model.

b. Initial -2 Log Likelihood: 180.714

c. Estimation terminated at iteration number 4 because parameter estimates changed by less than .001 . 
Tabel 4.9 Result of Overall Model Test Block 1: Method = Enter

\begin{tabular}{|c|c|c|c|c|c|c|c|c|c|}
\hline \multirow{2}{*}{\multicolumn{2}{|c|}{ Iteration }} & \multirow{3}{*}{$\begin{array}{c}\begin{array}{c}-2 \text { Log } \\
\text { Likelihood }\end{array} \\
167.147\end{array}$} & \multicolumn{7}{|c|}{ Coefficient } \\
\hline & & & \multirow{2}{*}{$\frac{\text { Constant }}{2.392}$} & \multirow{2}{*}{$\frac{\text { Motivation }}{0.006}$} & \multirow{2}{*}{$\frac{\text { Expend }}{0.032}$} & \multirow{2}{*}{$\frac{\text { Behaviour }}{-0.024}$} & \multirow{2}{*}{$\frac{\text { Sex }}{-0.404}$} & \multirow{2}{*}{$\frac{\text { Income }}{0}$} & \multirow{2}{*}{$\begin{array}{c}\text { Plan } \\
-0.727\end{array}$} \\
\hline Step 1 & 1 & & & & & & & & \\
\hline & 2 & 157.288 & 2.706 & 0.017 & 0.048 & -0.04 & -0.632 & 0 & -1.104 \\
\hline & 3 & 154.132 & 2.138 & 0.032 & 0.048 & -0.047 & -0.713 & 0 & -1.23 \\
\hline & 4 & 153.912 & 2.028 & 0.036 & 0.048 & -0.05 & -0.747 & 0 & -1.263 \\
\hline & 5 & 153.911 & 2.019 & 0.036 & 0.047 & -0.05 & -0.75 & 0 & -1.266 \\
\hline & 6 & 153.911 & 2.019 & 0.036 & 0.047 & -0.05 & -0.75 & 0 & -1.266 \\
\hline
\end{tabular}

Iteration Historya ${ }^{b, c, d}$

a. Method: Enter

b. Constant is included in the model.

c. Initial -2 Log Likelihood: 180.714

d. Estimation terminated at iteration number 6 because parameter estimates changed by less than .001 .

\section{Coefficient of Determination}

The value of Nagelkerke R-Square on table 4.10 below, shows the ability of independent variable on explaining dependent variable is $21,5 \%$, and there are other factors, $100 \%-21,5 \%=78,5 \%$, outside of the model that can describe the dependent variable.

Table 4.10 Result of Pseudo R-Square Test Model Summary

\begin{tabular}{cccc}
\hline Step & $\mathbf{- 2}$ Log likelihood & Cox \& Snell $\mathbf{R}^{\mathbf{2}}$ & ${\text { Nagel kerke } \mathbf{R}^{\mathbf{2}}}$ \\
\hline 1 & $153.911^{\mathrm{a}}$ & 0.133 & 0.215 \\
\hline
\end{tabular}

Factors Determine Tourism Destination decision making of tourism destinations to Java Island and outside of Java Island. Income variable had positive effect on tourism activities which means the higher income is the higher possibility for someone to have tourism activities to the outside of Java, instead of in Java Island. The explanation for this is because when the respondents have high income, they have more capability to finance their wishes travelling to the outside of Java. Plan variable affected negatively, which means the more likely a person saves his money for vacation, the smaller possibility that he will choose to do tourism activities to the outside of Java. Otherwise, he prefers to have vacation in Java Island only. It is possible because the respondent wants to have vacation only in Java Island, and have allocated

Tabel 4.11 Hasil Pengujian Variabel

Variables in the Equation

\begin{tabular}{|c|c|c|c|c|c|c|c|}
\hline \multirow{2}{*}{ B } & \multirow{2}{*}{ S.E. } & \multirow{2}{*}{ Wald } & \multirow{2}{*}{ df } & \multirow{2}{*}{ Sig. } & \multirow{2}{*}{$\operatorname{Exp}(B)$} & \multicolumn{2}{|c|}{ 95\% C.I. For EXP (B) } \\
\hline & & & & & & Lower & Upper \\
\hline 0.036 & 0.038 & 0.923 & 1 & 0.337 & 1.037 & 0.963 & 1.117 \\
\hline 0.047 & 0.085 & 0.314 & 1 & 0.575 & 1.049 & 0.888 & 1.238 \\
\hline-0.05 & 0.032 & 2.455 & 1 & 0.117 & 0.951 & 0.894 & 1.013 \\
\hline-0.75 & 0.432 & 3.008 & 1 & 0.083 & 0.472 & 0.202 & 1.102 \\
\hline 0.001 & 0 & 8.536 & 1 & 0.003 & 0.986 & 0.964 & 1.105 \\
\hline-1.266 & 0.431 & 8.618 & 1 & 0.003 & 0.282 & 0.121 & 0.657 \\
\hline 2.019 & 2.492 & 0.657 & 1 & 0.418 & 7.532 & & \\
\hline
\end{tabular}

a. Variable(s) entered on step 1: Motivation, Expend, Behavior, Sex, Income, Plan.

Based on table 4.11. can be seen that income variable and plan (planning on tourism activities that is supported by allocating certain amount of money per month) is significant at $\alpha=10 \%$. Motivation Variable, financing variable, and buying behavior variable in tourism activities do not have any influence on the his money to spend night in a comfort hotel and to enjoy the vacation itself comfortably.

$Y$ (tourism destination): In the state (Java and outside of Java) and Overseas 


\section{Feasibiliy Study of Regression Model}

Ho : Model which is hypothesized fit the data

$\mathrm{Ha}$ : Model which is hypothesized unfit the data

The test is conducted by using Test of Hosmer and Lemeshow. Because the statistic value of Hosmer and Lemeshow Test is 0,583 >0,05 then the Ho is accepted and $\mathrm{Ha}$ is rejected. It means the model is able to predict its observation value.

Table 4.12 Result of Goodness of Fit Hosmer and Lemoshow Test

\begin{tabular}{cccc}
\hline Step & Chi-Square & df & Sig. \\
\hline 1 & 8.219 & 8 & 0.412 \\
\hline
\end{tabular}

\section{Overall Model Test :}

By comparing the value between -2 Log Likehood on Block Number $=0$ and -2 Log Likehood on Block Number $=1$, because of the impairment, it means this regression model is fit with the data.

Table 4.13 Result of Overall Model Test Block 0: Beginning Block

\begin{tabular}{|c|c|c|c|}
\hline \multirow{2}{*}{\multicolumn{2}{|c|}{ Iteration }} & \multirow{2}{*}{-2 Log likelihood } & \multirow{2}{*}{$\frac{\text { Coefficients }}{\text { Constant }}$} \\
\hline & & & \\
\hline \multirow[t]{2}{*}{ Step 0} & 1 & 269.239 & -0.224 \\
\hline & 2 & 269.239 & -0.225 \\
\hline
\end{tabular}

a. Constant is included in the model.

b. Initial -2 Log Likelihood: 269.239

c. Estimation terminated at iteration number 2 because parameter estimates changed by less than .001.

\section{Coefficient of Determination}

Value of Nagelkerke R-Square on table 4.15 below, shows the ability of independent variable on explaining dependent variable is $16,9 \%$, and there are other factors, $100 \%-21,5 \%=83,1 \%$, outside of the model that can describe the dependent variable. It is probably because this study is the first study in which there have not been any similar research previously.

Table 4. 15 Result of Pseude R-Square Test Model Summary

\begin{tabular}{cccc}
\hline Step & $\mathbf{- 2}$ Log likelihood & Cox \& Snell $\mathbf{R}^{2}$ & Nagel kerke $\mathbf{R}^{2}$ \\
\hline 1 & $242.754^{\text {a }}$ & 0.126 & 0.169 \\
\hline a. Estimation terminated at iteration number 5 because \\
parameter estimates changed by less than .001
\end{tabular}

\section{Factors Determine Tourism Destination}

Based on table 4.16. it can be seen that variable of motivation, variable of financing, and variable of income are significant at $\alpha=5 \%$. Parameter of motivation and income have positive value which means if the respondents' motivation and income gets higher, then there will be high possibility for them to have vacation overseas. It is possible since the respondents also want to enjoy the beauty of tourism overseas, so when their income increases the possibility to travel abroad will rise. Variable of financing for travelling affected negatively, which means when the respondents tend to pay for their tour by using cash money, they will prefer to travel in the state rather than travelling abroad. It is possible because the fund needed to travel in the state is cheaper than that to travel abroad even though the respondents make a tour plan and save their money every month.

Tabel 4.14 Result of Overall Model Test Block 1: Method=Enter

\begin{tabular}{|c|c|c|c|c|c|c|c|c|c|}
\hline \multicolumn{2}{|c|}{ Iteration } & \multirow{2}{*}{$\begin{array}{c}\begin{array}{c}-2 \text { Log } \\
\text { Likelihood }\end{array} \\
246.424\end{array}$} & \multicolumn{7}{|c|}{ Coefficient } \\
\hline Step 1 & 1 & & $\begin{array}{c}\text { Constant } \\
-2.914\end{array}$ & $\begin{array}{c}\text { Motivation } \\
0.07\end{array}$ & $\begin{array}{c}\text { Expend } \\
-0.097\end{array}$ & $\begin{array}{c}\text { Behaviour } \\
0.027\end{array}$ & $\begin{array}{c}\text { Sex } \\
0.023\end{array}$ & $\frac{\text { Plan }}{0.509}$ & $\frac{\text { Income }}{0}$ \\
\hline & 2 & 242.929 & -3.403 & 0.084 & -0.122 & 0.027 & -0.037 & 0.504 & 0 \\
\hline & 3 & 242.754 & -3.576 & 0.087 & -0126 & 0.026 & -0.049 & 0.514 & 0 \\
\hline & 5 & 242.754 & -3.586 & 0.088 & -0.126 & 0.026 & -0.049 & 0.515 & 0 \\
\hline
\end{tabular}


Table 4.16 Variable Test Result Variables in the Equation

\begin{tabular}{|c|c|c|c|c|c|c|c|c|}
\hline \multirow{2}{*}{ Variable } & \multirow{2}{*}{ B } & \multirow{2}{*}{ S.E. } & \multirow{2}{*}{ Wald } & \multirow{2}{*}{ df } & \multirow{2}{*}{ Sig. } & \multirow{2}{*}{$\operatorname{Exp}(B)$} & \multicolumn{2}{|c|}{ 95\% C.I. For EXP (B) } \\
\hline & & & & & & & Lower & Upper \\
\hline Motivation & 0.088 & 0.029 & 8.942 & 1 & 0.003 & 1.092 & 1.031 & 1.156 \\
\hline Financing & -0.126 & 0.061 & 4.292 & 1 & 0.038 & 0.882 & $0 . .783$ & 0.993 \\
\hline Behaviour & 0.026 & 0.025 & 1.089 & 1 & 0.297 & 1.027 & 0.977 & 1.078 \\
\hline Sex & -0.049 & 0.328 & 0.023 & 1 & 0.880 & 0.952 & 0.5 & 1.811 \\
\hline Plan & 0.515 & 0.335 & 2.367 & 1 & 0.124 & 1.673 & 0.869 & 3.223 \\
\hline Income & 0.001 & 0 & 9.549 & 1 & 0.002 & 1.089 & 1.029 & 1.138 \\
\hline Constant & -3.586 & 1.623 & 4.879 & 1 & 0.027 & 0.027 & & \\
\hline
\end{tabular}

a. Variable(s) entered on step 1: Motivation, Expend, Behavior, Sex, Income, Plan.

\section{Buying Behavior}

To analyze the buying behavior, the researcher will calculate the mean score of each question, and then define the position of each group as tabulated in the table 4.17. The result of grouping of mean score value for each question can be seen on the table 4.18 in order to emphasize the buying behavior for each indicator.

Table 4.17 Range of Group Consumptivism

\begin{tabular}{lc}
\hline \multicolumn{1}{c}{ Group } & Range \\
\hline Not Consumtive & $0-1$ \\
Little bit Consumtive & $1.1-2$ \\
Consumtive & $2.1-3$ \\
High Consumtive & $3.1-4$ \\
Very High Consumtive & $4.1-5$ \\
\hline
\end{tabular}

Table 4.18 Consumptive Behavior on Types of Spending

\begin{tabular}{lccc}
\hline \multicolumn{1}{c}{ Types of Spending } & Total Score & Mean Score & Meaning \\
\hline Hotel & 638 & 3.24 & $\mathrm{HC}$ \\
Food & 522 & 2.65 & $\mathrm{C}$ \\
Snack & 427 & 2.17 & $\mathrm{C}$ \\
Entrance Ticket & 577 & 2.93 & $\mathrm{C}$ \\
Games/Entairtain & 562 & 2.85 & $\mathrm{C}$ \\
Own Cloths & 610 & 3.10 & $\mathrm{HC}$ \\
Souvenir & 607 & 3.10 & $\mathrm{HC}$ \\
Snack as Gift & 627 & 3.16 & $\mathrm{HC}$ \\
Cloths as Gift & 659 & 3.35 & $\mathrm{HC}$ \\
\hline
\end{tabular}

Remark: $\mathrm{C}=$ Consumptive $H C=$ High Consumptive

The table shows that averagely the students of Master's Degree very consumptive on spending for hotel, clothes, souvenirs, and gifts. On the other hand, the spending for food, snacks, entrance ticket, and games, is categorized as consumptive only.

\section{Ways to finance tourism activities}

In the analysis and discussion about how to finance tourism activities, the researcher do not distinguish between consumptive behavior during the vacation in Java Island, outside of Java Island, and Overseas.

Table 4.19 Result of Mean Score Value

\begin{tabular}{lccc}
\hline \multicolumn{1}{c}{ Financing } & Total Score & Mean Score & Meaning \\
\hline Monthly Alocation & 667 & 3.39 & VA \\
Self Financing & 781 & 3.96 & VA \\
Parent Financing & 464 & 2.36 & RA \\
Office Financing & 620 & 3.15 & VA \\
Cash & 749 & 3.8 & VA \\
Credit Card & 458 & 2.32 & RA \\
\hline $\begin{array}{l}\text { VA = Very Agree } \\
R A=\text { Relatif Agree }\end{array}$ & & &
\end{tabular}

Table 4.19. that provides the result of grouping of mean score value for each question, can show the big picture of how to finance tourism activities.

First respondents 'very agree' towards the statement of "monthly allocation" which means the respondents tend to allocate their money every month to finance their vacation planning. It also means that respondents have prepared good financial plan to pay its vacation which usually needs huge amount of money.

Second respondents "very agree" with the statement of 'self-financing', which means the respondents tend to finance its tourism activities by themselves. This phonemenon probably relates to the status of 
respondents which mostly are married, so they have responsibility towards its family needs, including tourism activities.

Third respondents 'quiet disagree' with the statement "parents' financing" This statement is a repeated statement from the previous negative statement. The result of "quiet disagree" which is similar to the previous result proves that the respondents answered the question appropriately and conistently.

Fourth respondents very agree with statement "office's financing", which means if the office offers for vacation by using office money, then the respondents will definitely take that chance.

Fiveth respondents very agree with statement "cash payment" which means they prefer to pay its vacation's cost by using cash rather than using credit card. It probably relates to the fact on point ' $a$ ' that respondents have allocated money to finance its vacation so they can pay the cost by cash.

Sixth respondents 'quiet disagree' with the statement "paying by using credit card" This statement is a repeated statement from the previous negative statement. The result of "quiet disagree' which is similar to the previous result proves that the respondents answered the question appropriately and consistently.

Overall, it can be concluded that the respondents have made planning on doing vacation as shown on table 4.19. In addition, the respondents also have allocated their money to finance its tourism activities regularly, even though the tourism activities here mean activities conducted by their office. Mostly payment for vacation is paid by cash and do not use parents' money.

\section{CONCLUSION}

This study is the first study in touring consumtivism that previously there have not been any researches in this field, especially in Indonesia. The data collected was gained by giving questionnaire to the Master's Degree Students in 9 (nine) Universities in Jakarta. The researchers handed out 216 questionnaires and received 199 questionnaires that were returned by the respondents.

This study is about the selection of tourism destination which is affected by some independent variables such as motivation, spending, buying behavior, gender, income and plan for tourism spending. The independent variable, tourism destination, is analyzed by using binary logistic regression. Analysis was conducted two times, the first one is to the tourism destination in Java Island and outside of Java Island, and the second one is tourism destination in the state and overseas.

Based on the result of discussion and data analysis, it can be emphasized that: The first, respondents are consumptive on spending their money for food, snacks, entrance ticket, and entertainment. In addition, they are very consumptive on spending money on hotel, clothes for themselves and for family/ friends, souvenirs, and snacks as gifts. The second, income and plan (respondents' preparation by saving their income monthly to finance their vacation) are factors that stimulate them to decide whether they will have vacation in Java Island or outside of Java Island, whereas the factors that encourage them to have vacation in the state or overseas are motivation, funding, and income. The third, whether the tourism destination is in Java Island or outside Java Island, as well as domestic or overseas, mostly respondents chose to pay their cost by using their cash own money or by using credit card for the range of $1-6$ months payment. It is possible because they have planned its vacation and have saved money monthly for that vacation.

By this study, researchers have aim to tourism marketers should understand the sensation-seeking desires of their guests and visitors and should not only tailor their advertising and promotional efforts to the desired level of arousal of their market but also adapt their environment to best satisfy these desires.

\section{Recomendation}

For the next research, the researcher suggest as follows:

First to add the number of respondents and to expand the scope area for questionnaire to be not only in Jakarta. 
Second to continue this study for digging further and expanding the scope of study so other variables can be found and put into this model of study.

Third to conduct similar study with the respondents from group which has different background such as Doctoral students of High school's students, and then compare the result of those two groups.

\section{REFERENCES}

Enrico, A., Aron, R., \& Oktavia, W. (2014). The Factors that Influenced Consumptive Behavior: A Survey of University Students in Jakarta. International Journal of Scientific and Research Publications, Volume 4, Issue 1.

Ali, A. J., \& Wisniesk, J. M. (2010). Consumerism and ethical attitudes: an empirical study. International Journal of Islamic and Middle Eastern Finance and Management. Vol. 3 No. 1.

Berkman, H. C., \& Gilson, C. C. (1978). Consumer behavior- Concepts and strategies. Dickensoublishing Company, Inc, 521-524

Chon, K. (1990). The role of destination image in tourism: A review and discussion, The Tourist Review, February, pp. 2-9.

Demeter, T. \& Brautucu, G. (2014). Typologies Of Youth Tourism. Bulletin of Transilvania University of Brasov. Series V: Economics Sciences, Vol 7 (56).

Ferdinand, A. (2014). Metode Penelitian. Undip Press. Edisi 5.

Fratu, D. (2011). Factors of Influence and changes in the Tourism Consumer Behavior. Bulletin of the Transilvania University of Brasov. Vol. 4 (53). No. 1 - 2011. Series V: Economic Sciences.

Grande, I. (2005). Dimensions in scales for measuring exploratory tendencies and stimulation levels in consumers: a cross-cultural comparison of the USA and Spain. Journal of Consumer Behavior. Vol 4 (5), 363-373.

Higgins, F. \& Desbiolles. (2010). The Elusiveness of Sustainability in Tourism: The CultureIdeology of Consumerism and its Implications. Tourism and Hospitality Research. Vol 10, 2.

Ismail, H. B. \& Panni, M. F. A. K. (2008). Consumer perceptions on the issues and its influence on their purchasing behavior: a view from Malaysia Food industry. Journal of Legal, Ethical and Regulatory Issues, Volume 11, Number 1.

Ismail, H. B., Panni, M. F. A. K., \& Talukder, Di. (2006). Consumerperceptions on the environmental consumerism issue and its influence on their purchasing behavior. Allied Academies International Conference.

Jones, P., Hillier, D., Comfort, Daphne, \& Eastwood, I. (2005). Sustainable Retailing and Concumerism. Management Research News, Vol 28, 1.

Lamarto, (1985) Prinsip Pemasaran., Jilid I., Jakarta: Erlangga.

Litvin, S. W. (2008). Sensation seeking and its measurement for tourism research. Journal of Travel Research. Vol 46, 440-445.

Litvin, S. \& Ling, S. (2000). The destination attribute management model: an empirical application to Bintan, Indonesia, Tourism Management, 22, pp. 481-492.

Lubis, Y. (1993). Pola Hidup Konsumtif: Antara Kapitalisme dan Nafsu Prestise. Ekonomika. 1..XVII.47.Yogyakarta

Mullins, P. (1999). Managing Tourism in Cities: Policy, Process and Practice. Urban Studies, Vol 36, 11; ProQuest.

Orel, F. D. \& Zeren, D. (2011). Business Students' Attitudes towards Consumerism, Marketing Practices and Government Regulations: A 
Comparative Study of Poland and Turkey. International Journal of Business and Social Science. Vol. 2 No. 19.

Radbata, A., \& Fratu, D. (2010). Place Branding. Case Study: Branding Romania. Brasov. In: International Conference Business Excellence. No.2, p. 110-114

Sekaran, U., \& Bougie, R. (2010). Research Methods For Business A Skill Building Approach. Chichester, West Sussex: John Wiley \& Sons Ltd.
Sharpley, R. (1994). Tourism, Tourist and Society. Chambridgeshire: ELM Publication.

Solomon, M. R. (2012). Consumer Behavior. Prentice Hall. 10th Edition.

Ware, C. L. (2002). Consumerism, Credit Cards and College Student. A Dissertation submitted to the faculty of the department of humanities in candidacy for the degree of doctor of philosophy. 